\title{
DEVELOPMENT OF MALE STERILE BROCCOLI LINES WITH RAPHANUS SATIVUS CYTOPLASM AND ASSESSMENT OF THEIR VALUE FOR BREEDING PURPOSES
}

\author{
Piotr KAMIŃSKI* \\ Research Institute of Horticulture \\ Konstytucji 3 Maja 1/3, 96-100 Skierniewice, Poland \\ Received: July 9, 2013; Accepted: December 4, 2013
}

\begin{abstract}
The aim of this study was to obtain new broccoli lines with cytoplasmic male sterility trait for the development of the modern $\mathrm{F}_{1}$ hybrids. CDT70 cauliflower line obtained in the Research Institute of Horticulture, formerly Research Institute of Vegetable Crops, Skierniewice, Poland, with the reliable cytoplasmic male sterility from Raphanus sativus (Ogu-INRA) was selected as a source of this trait. Three broccoli lines: $\mathrm{BMi}, \mathrm{BCr} 1$ and $\mathrm{BCr} 2$ were used as donors of commercial characters in all cross combinations with sterile components. Selected fertile broccoli genotypes were characterized by good quality, uniformity and high level of self-compatibility. The breeding procedure included three consecutive back crosses of male sterile genotypes with fertile broccoli lines that lasted from 2008 to 2012. In each generation, self-compatibility level, the stability of the male sterility trait and ability for the generative propagation of back-crossed genotypes were tested in comparison with donor broccoli lines in the greenhouse. The agronomical and morphological characters of the back-crossed progeny were also evaluated in the field. As a result, three CMS broccoli lines of $\mathrm{Bc}_{3}$ generation with good quality and high seeding index, suitable for the breeding purposes, were obtained.
\end{abstract}

Key words: broccoli (Brassica oleracea L. var. italica Plenck), cytoplasmic male sterility, morphological traits, self-compatibility, breeding, hybrids

\section{INTRODUCTION}

Cytoplasmic male sterility among Brassica oleracea was broadly investigated to implement it as a low-cost, efficient and reliable system for the production of $\mathrm{F}_{1}$ hybrids that could be easily utilized by breeders (Kamiński et al. 2012). In Brassica genus, male sterile plants were obtained from intervarietal crosses in B. napus (Shiga \& Baba 1973); spontaneous male sterile plants were also isolated among Brassica juncea with the cytoplasm of related wild species B. tournefortii (Pradhan et al. 1991). However, male sterility discovered by Ogura (1968) in Japanese radish (Raphanus sativus) became the most intensively investigated $C M S$ system among crop plants. Presently male sterility with
Ogu-INRA cytoplasm provides one of the most efficient means of directed pollination for the largescale production of hybrid seeds in crops (Prakash et al. 2009a). Male sterility of alloplasmic lines derived from wide hybridization with nuclear and mitochondrial genomes from different species manifests usually in defective floral development as a result of incompatibility of nuclear-mitochondrial interaction. Male sterility may have a spontaneous character or may arise after intraspecific, interspecific or intergeneric crosses (Kaul 1988). Utilization of maternally inherited cytoplasmic male sterility encoded in mitochondrial genes can be more effective than genic male sterility. CMS can be also considered as a genetic system with two genetic determinants with different modes of inheritance, at the cytoplasmic and the nuclear levels (Budar et al. 
2006). Interaction of the cytoplasm of one species with the nuclear genome of the other parent in interspecific crosses is often linked to cytoplasmic male sterility (Bannerot et al. 1977). Improvement of female fertility and cold tolerance via protoplast fusion (Pelletier et al. 1983; Yarrow et al. 1996; Jourdan et al. 1989) made the CMS-Ogura system the most popular one used for the modern breeding of broccoli, cauliflower and other cabbages as well as for rapeseed $F_{1}$ hybrids. Generally, the cytoplasm donor species from which the sterility originates also provides the nuclear restorers (Heyn 1976; Pellan-Delourme \& Renard 1988; Delourme et al. 1991, 1999; Prakash et al. 1998). The Ogura sterility in all B. oleracea species does not have any fertility restorer genes, while all fertile forms serve as maintainers (Dixon 2007; Prakash et al. 2009b). Breeding of the modern broccoli $F_{1}$ cultivars required introducing cytoplasmic male sterility trait into maternal components from other closely related species such as cauliflower or cabbage.

The aim of this study was an evaluation of the possibility of obtaining the male sterile broccoli genotypes with Raphanus sativus cytoplasm with the use of classical breeding procedures and the investigation of the progeny according to the ability for generative propagation and evaluation of the quality of agronomical traits.

\section{MATERIALS AND METHODS}

\section{Development of broccoli male sterile lines}

Cytoplasmic male sterile cauliflower line CDT70 with cytoplasm from Raphanus sativus developed in the Research Institute of Horticulture, Skierniewice, was chosen as a source of CMS trait. In 2008, it was crossed at open flower stage in the greenhouse as maternal component with five fertile broccoli inbreeds of good quality. In the result of selection in the consecutive generations, only three self-compatible broccoli genotypes (BMi, $\mathrm{BCr} 1$, $\mathrm{BCr} 2)$ were taken as superseding parents. From 2008 until 2012, three back-crosses of male sterile progeny with three broccoli superseding lines were made. For each of the back-crossed generations $\left(\mathrm{Bc}_{1}-\mathrm{Bc}_{3}\right)$, selection for desired morphological characters and for ability to generative propagation was performed both at the field and in the greenhouse. Only CMS plants with typical flower structure for $O g u-I N R A$ cytoplasm and high level of selfcompatibility were selected as donors of maternally inherited cytoplasmic male sterility.

Cross-pollination of male sterile cauliflowers with fertile broccoli plants required synchronization of sowing dates to find an appropriate moment, enabling effective cross-pollination when both components have enough flowers. For this reason, in the following years fertile components were sown 10 days earlier than the sterile ones. Consecutive backcross generations of broccoli-cauliflowers with sterile cytoplasm and broccoli superseding lines were sown at the end of January in the greenhouse. Fertilization and plant protection against pests and diseases followed current requirements and recommendations for broccoli and cauliflower. At the beginning of June, each pair of CMS and appropriate superseding line was crossed at open flower stage. Seven to ten flowers were pollinated by hand during blooming season for each of the selected genotype. Seed stacks were covered by bags made from paper and transparent film to avoid undesired pollination by insects. Flowers and seed stalks were screened during their blooming according to their morphology, especially the ability to form male sterile or fertile flowers. From the second decade of August until the beginning of September, matured silicas were gradually harvested separately for each of the plants. After silicas were dried, seeds were extracted, cleaned and weighed separately.

\section{Field evaluation of broccoli CMS lines}

Male sterile and fertile broccoli lines that developed a sufficient amount of seeds were evaluated in the field according to commercial and agronomical characters. In the second decade of June, onemonth-old seedlings were planted in the field (spacing $50 \times 50 \mathrm{~cm}$ ) in a completely randomized block design (plots) with three replications. Each plot consisted of 10 plants in one row. The soil type was a pseudopodsolic over loamy sand $(1.5 \%$ organic matter, $\mathrm{pH}$ 6.5). Fertilization, pest and disease control followed the current recommendations for broccoli. Plants were harvested gradually from the beginning of August till the end of September at curds maturity. Average mass of curds and number of 
days from planting to harvest were evaluated and additional morphological characteristics of broccoli population such as intraline uniformity, vigor, color, and quality of curds were assessed separately for each plot according to a multigrade scale. Three commercial $F_{1}$ hybrids ('Marathon', 'Monopoly', 'Montop') and one open-pollinated cultivar 'Cezar' were used as a control for the field trial in 2012. Data on the weight of curds were subjected to an analysis of variance (ANOVA). The significance of differences among means was evaluated by Duncan's test at $\mathrm{p}=0.05$.

\section{RESULTS AND DISCUSSION}

Cauliflower line CDT70 used as a source of cytoplasmic male sterility in 2008 was characterized by good quality typical for summer varieties, with medium length of vegetation (63 days after planting), white, firm curd, mass of $513 \mathrm{~g}$ and good internal uniformity (Fig. 1A). Male sterile cauliflower started to bloom 10 days earlier than male fertile broccoli lines. At the generative stage, CDT70 line developed flowers with yellow petals, reduced in size anthers without pollen. Male sterile cauliflower, selected as a source of CMS trait, formed an average of 16 seeds per silica when pol- linated at the open flower stage and was characterized by good maternal fertility and high level of self-compatibility (Table 1). Four fertile lines of broccoli, selected as paternal components for the crosses with sterile cauliflower, were uniform with green color of curds and good commercial quality (Fig. 1B). The highest mass of curds was noticed for MD130 line $(558 \mathrm{~g})$, and the lowest for ZR138 $(259 \mathrm{~g})$. Vegetation period from planting to harvest ranged from 53 for ZR138 line to 76 days (LD315). All broccoli genotypes developed yellow flowers with anthers and fertile pollen; however, they had diversified level of self-compatibility when pollinated at open flower stage. Two genotypes, ZR138 and MD130, showed high level of self-compatibility (10 and 7 seeds per silica respectively), while MR314 and LD315 lines did not develop seeds when pollinated at open flower stage (Table 1). Two interspecific $\mathrm{F}_{1}$ hybrids $(\mathrm{CDT} 70 \times \mathrm{ZR} 138, \mathrm{CDT} 70$ $\times$ MD130), obtained as a result of crosses between male sterile cauliflower and fertile broccoli, showed intermediate characters of both parents when tested in the field in 2009 (Table 2). They developed yellow curds with flattened shape and bracting, without covering by internal leaves and with higher mass in comparison with their broccoli superseding components (Fig. 1C).

Table 1. Morphological and commercial traits of male sterile cauliflower and male fertile broccoli lines. Skierniewice 2008

\begin{tabular}{ccccccccc}
\hline Genotype & $\begin{array}{c}\text { Unifor- } \\
\text { mity }^{1}\end{array}$ & $\begin{array}{c}\text { Color } \\
\text { of curd }\end{array}$ & $\begin{array}{c}\text { Vigor } \\
\text { (2urd }\end{array}$ & $\begin{array}{c}\text { Mass } \\
\text { quality }\end{array}$ & $\begin{array}{c}\text { Length of } \\
\text { vegetation } \\
(\mathrm{g})\end{array}$ & $\begin{array}{c}\text { Male } \\
\text { (no. of days } \\
\text { from planting } \\
\text { to harvest) }\end{array}$ & $\begin{array}{c}\text { No. of } \\
\text { sterility/ } \\
\text { fertility }\end{array}$ & $\begin{array}{c}\text { seeds/ } \\
\text { silique }\end{array}$ \\
\hline $\begin{array}{c}\text { Cauliflower line } \\
\text { CDT 70 }\end{array}$ & 1 & 1 & 1 & 1 & 513 & 63 & sterile & 16.0 \\
\hline $\begin{array}{c}\text { Broccoli lines } \\
\text { ZR 138 }\end{array}$ & 1 & 5 & 2 & 1 & 259 & 53 & fertile & 10.0 \\
MD 130 & 1 & 5 & 1 & 1 & 558 & 65 & fertile & 7.0 \\
MR 314 & 1 & 5 & 1 & 1 & 376 & 54 & fertile & 0.0 \\
LD 315 & 1 & 5 & 1 & 1 & 441 & 76 & fertile & 0.0 \\
\hline
\end{tabular}

${ }^{1}$ Uniformity: 1 - complete, 2 - partial, 3 - lack of uniformity

${ }^{2}$ Color of curd: 1 - white, 2 - creamy, 3 - yellow, 5 - green

${ }^{3}$ Vigor: 1 - high, 2 - medium, 3 - low

${ }^{4}$ Quality of curd: 1 - commercial quality, 2 - slight defects, 3 - non-commercial with major defects 
Table 2. Morphological and commercial traits of male-sterile cauliflower, superseding broccoli genotypes and their $\mathrm{F}_{1}$ hybrids. Skierniewice 2009

\begin{tabular}{|c|c|c|c|c|c|c|c|c|}
\hline Genotype & $\begin{array}{l}\text { Uni- } \\
\text { for- } \\
\text { mity }{ }^{1 *}\end{array}$ & $\begin{array}{l}\text { Color } \\
\text { of } \\
\text { curd }^{2}\end{array}$ & Vigor $^{3}$ & $\begin{array}{l}\text { Curd } \\
\text { qua- } \\
\text { lity }\end{array}$ & $\begin{array}{c}\text { Mass } \\
\text { of curd } \\
\quad(g)\end{array}$ & $\begin{array}{l}\text { Length of } \\
\text { vegetation } \\
\text { (no. of days } \\
\text { from planting } \\
\text { to harvest) }\end{array}$ & $\begin{array}{c}\text { Male } \\
\text { sterility/ } \\
\text { fertility }\end{array}$ & $\begin{array}{l}\text { No. of } \\
\text { seeds/ } \\
\text { silique }\end{array}$ \\
\hline \multicolumn{9}{|l|}{ Cauliflower line } \\
\hline CDT 70 & 1 & 1 & 1 & 1 & 512 & 63 & sterile & 19.0 \\
\hline \multicolumn{9}{|l|}{ Broccoli lines } \\
\hline ZR 138 & 1 & 5 & 2 & 1 & 269 & 54 & fertile & 7.0 \\
\hline MD 130 & 1 & 5 & 1 & 1 & 568 & 65 & fertile & 12.0 \\
\hline \multicolumn{9}{|l|}{$F_{1}$ hybrids } \\
\hline $\mathrm{ZR} 138 \times \mathrm{CDT} 70 \mathrm{~F}_{1}$ & 3 & 3 & 1 & 3 & 426 & 58 & sterile & 6.0 \\
\hline $\mathrm{MD} 130 \times \mathrm{CDT} 70 \mathrm{~F}_{1}$ & 3 & 3 & 1 & 3 & 674 & 60 & sterile & 9.0 \\
\hline
\end{tabular}

*see Table 1

Flowers of interspecific hybrids were sterile and formed six to nine seeds per silica when pollinated with broccoli superseding lines. In 2011, after two consecutive backcrosses pollinations of male sterile population with superseding broccoli components at open flower stage, a constant improvement in quality and higher uniformity in curds were observed (Fig. 1D). Three populations of sterile broccoli $\mathrm{Bc}_{2}$ generation were not uniform (Fig. 1E) with slightly lighter color of curds in comparison with their broccoli superseding lines. The average mass of curds of male sterile genotypes was comparable to fertile broccoli lines and ranged from 240 (CZR238 $\left.\mathrm{Bc}_{2}\right)$ to $340 \mathrm{~g}$ (ZR138). Vegetation period from planting to harvest was similar for all tested forms (56-60 days). Plants of $\mathrm{Bc}_{2}$ generation were sterile and developed from 5.1 to 24.5 g seeds per plant (CMD130 $\mathrm{Bc}_{2}, \mathrm{CZR} 238 \mathrm{Bc}_{2}$ ), respectively, when pollinated by bees in the isolated growth cages. Three fertile broccoli superseding lines used for the backcrosses formed from 30.8 (MD130) to $9.8 \mathrm{~g}$ of seeds per plant (ZR238) (Table 3). Male sterile lines of $\mathrm{Bc}_{3}$ generation evaluated in the field in 2012 were more uniform in comparison with $\mathrm{Bc}_{2}$ generation according to tested traits and they did not differ significantly from their superseding lines, according to the mass of curd, and had the same color, similar vigor and length of vegetation period (Table 4). The quality of curds of $\mathrm{Bc}_{3}$ sterile lines was as good as experimental $F_{1}$ hybrids and the commercial cultivars used as a control (Fig. 1F). However, their mass of curd was significantly lower than the best yielding commercial $F_{1}$ hybrids: 'Monopoly' and 'Montop'.

The results in obtaining male sterile broccoli genotypes with $O g u$-INRA cytoplasm underlined higher effectiveness of the repeated back-crossings of the $F_{1}$ hybrids between valuable breeding lines and a source of CMS-Ogura, which was a confirmation of results reported by Budar et al. (2006), Dixon (2007), Kaul (1998) and Prakash (2009). Large number of hybrid varieties were developed among oilseed Brassica based on improved Ogu-INRA CMS system by various seed companies (Prakash et al. 2009). Cauliflower line used as a donor of male sterility and newly obtained broccoli genotypes with Raphanus sativus cytoplasm described in this paper have high potential for generative propagation by seeds typical for Ogu-INRA (Dixon 2007). Seed effectiveness of cauliflowers with Raphanus sativus cytoplasm was also higher than for the genotypes with Brassica nigra cytoplasm (Kamiński et al. 2012). Good quality of curds at $\mathrm{Bc}_{3}$ generation of male sterile broccoli lines and lack of negative effects of Raphanus sativus cytoplasm showed a high value of obtained material.

The results suggest that the development of diversified broccoli lines with cytoplasmic male sterility trait can be an effective method for production of vigorous and uniform $F_{1}$ hybrids, which could be more attractive than open-pollinated cultivars. 

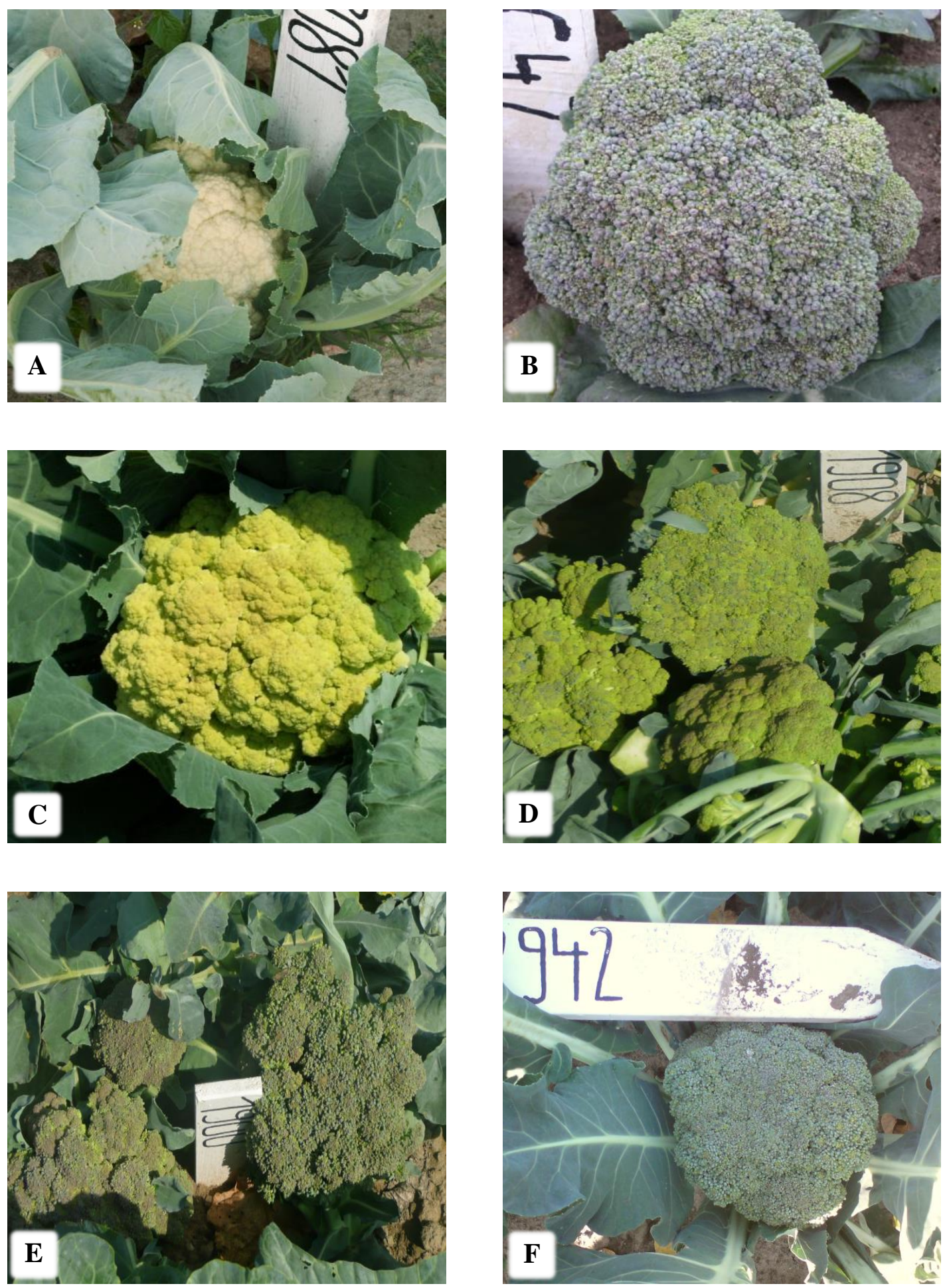

Fig. 1. Morphological characters of curds; A - DT70 male sterile cauliflower line with Raphanus sativus cytoplasm used as maternal parent, B - ZR238 fertile broccoli parental line used as donor of pollen, C - F 1 hybrid (DT70 $\times$ ZR238), $\mathrm{D}-\mathrm{Bc}_{1}$ generation, $\mathrm{E}-\mathrm{Bc}_{2}$ generation, $\mathrm{F}-\mathrm{Bc}_{3}$ generation with quality typical for broccoli superseding line 
Table 3. Morphological and commercial traits of superseding broccoli genotypes and $\mathrm{Bc}_{2}$ generation. Skierniewice 2011

\begin{tabular}{|c|c|c|c|c|c|c|c|c|}
\hline Genotype & Uniformity $^{1 *}$ & $\begin{array}{l}\text { Color } \\
\text { of } \\
\text { curd }^{2}\end{array}$ & Vigor $^{3}$ & $\begin{array}{c}\text { Curd } \\
\text { quality }^{4}\end{array}$ & $\begin{array}{c}\text { Aver. } \\
\text { mass } \\
\text { of curd } \\
\quad(g)\end{array}$ & $\begin{array}{l}\text { Length of } \\
\text { vegetation } \\
\text { (no. of days } \\
\text { from plant- } \\
\text { ing to har- } \\
\text { vest) } \\
\end{array}$ & $\begin{array}{c}\text { Male } \\
\text { sterility/ } \\
\text { fertility }\end{array}$ & $\begin{array}{l}\text { Average mass of } \\
\text { seeds/plant after } \\
\text { sib-pollination in } \\
\text { the growth-cage } \\
\text { (g) }\end{array}$ \\
\hline \multicolumn{9}{|c|}{ Broccoli lines } \\
\hline ZR 138 & 1 & 5 & 2 & 1 & 340 & 56 & fertile & 19.9 \\
\hline ZR 238 & 1 & 5 & 3 & 1 & 290 & 56 & fertile & 9.8 \\
\hline MD 130 & 1 & 5 & 1 & 1 & 270 & 60 & fertile & 30.8 \\
\hline \multicolumn{9}{|c|}{ Bc $c_{2}$ generation } \\
\hline CZR 138 & 2 & 4 & 3 & 2 & 310 & 56 & sterile & 16.0 \\
\hline CZR 238 & 2 & 4 & 3 & 2 & 240 & 56 & sterile & 5.1 \\
\hline CMD & 2 & 5 & 3 & 2 & 270 & 60 & sterile & 24.5 \\
\hline
\end{tabular}

*see Table 1

Table 4. Morphological and commercial traits of broccoli male-fertile superseding genotypes, male-sterile genotypes of $\mathrm{Bc}_{2}, \mathrm{Bc}_{3}$ generations and experimental $\mathrm{F}_{1}$ hybrids. Skierniewice 2012

\begin{tabular}{|c|c|c|c|c|c|c|c|}
\hline Genotype & Uniformity $^{1 *}$ & $\begin{array}{l}\text { Color } \\
\text { of } \\
\text { curd }^{2}\end{array}$ & Vigor $^{3}$ & $\begin{array}{c}\text { Curd } \\
\text { quality }\end{array}$ & $\begin{array}{l}\text { Mass of } \\
\text { curd }(\mathrm{g})\end{array}$ & $\begin{array}{l}\text { Length of } \\
\text { vegetation } \\
\text { (no. of days } \\
\text { from planting } \\
\text { to harvest) }\end{array}$ & $\begin{array}{c}\text { Male } \\
\text { sterility/ } \\
\text { fertility }\end{array}$ \\
\hline \multicolumn{8}{|l|}{ Broccoli lines } \\
\hline ZR 138 & 1 & 5 & 2 & 1 & 260 & 56 & fertile \\
\hline ZR 238 & 1 & 5 & 3 & 1 & 274 & 58 & fertile \\
\hline MD 130 & 1 & 5 & 2 & 1 & 140 & 60 & fertile \\
\hline \multicolumn{8}{|l|}{$\mathrm{Bc}_{2}$ generation } \\
\hline $\mathrm{CMD} 130 \mathrm{Bc}_{2}$ & 2 & 5 & 2 & 2 & 160 & 60 & sterile \\
\hline CZR $238 \mathrm{Bc}_{2}$ & 2 & 4 & 3 & 2 & 293 & 58 & sterile \\
\hline $\mathrm{CZR} 138 \mathrm{Bc}_{2}$ & 2 & 4 & 3 & 2 & 295 & 56 & sterile \\
\hline \multicolumn{8}{|l|}{ Bc3 generation } \\
\hline CZR $238 \mathrm{Bc}_{3}$ & 1 & 5 & 3 & 1 & 244 & 58 & sterile \\
\hline CMD $130 \mathrm{Bc}_{3}$ & 1 & 5 & 2 & 1 & 178 & 60 & sterile \\
\hline CZR $138 \mathrm{Bc}_{3}$ & 1 & 5 & 3 & 1 & 268 & 56 & sterile \\
\hline \multicolumn{8}{|c|}{ Experimental $F_{1}$ hybrids } \\
\hline CZR $138 \times$ MD $130 \mathrm{~F}_{1}$ & 1 & 5 & 3 & 1 & 296 & 62 & sterile \\
\hline $\mathrm{CMD} 130 \times \mathrm{ZR} 238 \mathrm{~F}_{1}$ & 1 & 5 & 3 & 1 & 284 & 58 & sterile \\
\hline \multicolumn{8}{|l|}{ Control cultivars } \\
\hline Cezar & 1 & 5 & 3 & 1 & 263 & 56 & - \\
\hline Marathon $\mathrm{F}_{1}$ & 1 & 5 & 3 & 1 & 294 & 65 & - \\
\hline Monopoly $\mathrm{F}_{1}$ & 1 & 5 & 3 & 1 & 396 & 65 & - \\
\hline Montop $\mathrm{F}_{1}$ & 1 & 5 & 3 & 1 & 458 & 56 & - \\
\hline
\end{tabular}

*see Table 1 


\section{CONCLUSION}

Obtaining three broccoli male sterile lines with intraline uniformity and good quality was possible after five years of intensive breeding with the use of back-cross pollinations of progeny obtained from hybridization of good inbreed broccoli lines with cauliflower line possessing $O g u-I N R A$ cytoplasmic male sterility, consecutive selection for self-compatibility and morphological and commercial characters both in the greenhouse and in the field. High level of self-compatibility and good ability for generative propagation allow for the effective reproduction of parental components with the use of insect pollination.

However, the value of CMS lines presented in this paper and hybrids obtained with their use should be examined in different environmental conditions.

\section{REFERENCES}

Bannerot H., Boulidard L., Chupeau Y. 1977. Unexpected difficulties met with the radish cytoplasm in Brassica oleracea. Eucarpia Cruciferae Newsletter 2: 16.

Budar F., Pascal T., Pelletier G. 2006. Cytoplasmic male sterility. In: Flowering and its Manipulation. Ann. Plant Rev. Blackwell Publishing, 20: 147-180.

Delourme R., Budar F. 1999. Male sterility. In: GomezCampo C. (Ed.), Biology of Brassica Coenospecies, Elsevier, Amsterdam, pp. 185-216.

Delourme R., Eber F., Renard M. 1991. Radish cytoplasmic male sterility in rapeseed: breeding restorer lines with a good female fertility. Proceedings of 8th International Rapeseed Conference, Saskatoon, Saskatechewan, Canada.

Dixon G.R. 2007. Vegetable Brassicas and related crucifers. CAB International. Wallingford.

Heyn F.W. 1976. Transfer of restorer genes from Raphanus to cytoplasmic male sterile Brassica napus. Cruciferae Newsletter 1: 15-16.

Jourdan P.S., Earle E.D., Mutschler M.A. 1989. Synthesis of male-sterile, triazine-resistant Brassica napus by somatic hybridization between cytoplasmic male sterile $B$. oleracea and atrazine-resistant B. campestris. Theor. Appl. Genet. 78: 445-455.
Kamiński P., Dyki B., Stępowska A.A. 2012. Improvement of cauliflower male sterile lines with Brassica nigra cytoplasm, phenotypic expression and possibility of practical application. J. Agric. Sci. 4: 187 198. DOI: $10.5539 /$ jas.v4n4p190.

Kaul M.H. 1988. Male Sterility in Higher Plants, Springer-Verlag, Berlin, Heilderberg.

Ogura H. 1968. Studies on a new male-sterility in Japanese radish with special reference to utilisation of this sterility towards the practical raising of hybrid seeds. Mem. Fac. Agric. Kagoshima Univ. 6: 3678.

Pellan-Delourme R., Renard M. 1988. Cytoplasmic male sterility in rapeseed (Brassica napus L.): female fertility of restored repeseed with 'Ogura' and cybrid cytoplasms. Genome 30: 234-239.

Pelletier G., Primard C., Vedel F., Chetrit P., Remy R., Rousselle P., Renard M. 1983. Intergeneric cytoplasmic hybridization in Cruciferae by protoplast fusion. Mol. Gen. Genet. 191: 244-250.

Pradhan A.K., Mukhopadhyay A., Pental D. 1991. Identification of putative cytoplasmic donor of CMS system in Brassica juncea. Plant Breed. 106: 204 208. DOI: 10.1111/j.1439-0523.1991.tb00502.x.

Prakash S., Bhat S.R., Quiros C.F., Kirti P.B., Chopra V.L. 2009a. Brassica and its close allies: cytogenetics and evolution. Plant Breed. Rev. 31: 21-187. DOI: 10.1002/9780470593783.ch2.

Prakash S., Bhat S.R., Ting-Dong Fu 2009b. Wild germplasm and male sterility. In: Gupta S.K. (Ed.), Biology and breeding of crucifers. CRC Press, pp. 113-127.

Prakash S., Kirti P.B., Bhat S.R., Gaikwad K., Kumar V.D., Chopra V.L. 1998. A Moricandia arvensisbased cytoplasmic male sterility and fertility restoration system in Brassica juncea. Theor. Appl. Genet. 97: 488-492. DOI: 10.1007/s001220050921.

Shiga T., Baba S. 1973. Cytoplasmic male sterility in oilseed rape (Brassica napus L.) and its utilisation to breeding. Japan J. Breed. 23: 187-193.

Yarrow S.A., Wu S.C., Barsby T.L., Kemble R.J., Shepard J.F. 1986. The introduction of CMS mitochondria to triazine tolerant Brassica napus L., var. 'Regent', by micromanipulation of individual heterokaryons. Plant Cell Reports 5: 415-418. DOI: 10.1007/BF00269630. 